\title{
Resenha
}

BOSSERT, Federico \& VILLAR, Diego. Hijos de la selva/Sons of the Forest. La fotografía etnografica de Max Schmidt/The ethnographic photography of Max Schmidt. Edición de Viggo Mortensen, versión bilingüe español/inglés, Santa Mónica/California, Perceval Press, 2013, 136 pp., 86 fotografias. 21 figs.

\section{Rescate de un enfoque etnográfico velado en la Historia}

\author{
María Cristina Dasso \\ Centro de Investigaciones en Antropología Filosófica y Cultural \\ Buenos Aires, Argentina \\ mcdasso@fibertel.com.ar
}

En el libro que tratamos, el mapa de la expedición al Mato Grosso (1926-1928) abre con nosotros el camino hacia Max Schmidt, retratado en profundidad a través de su fotografía etnográfica y de los documentos que forman parte de su legado al Museo Etnográfico Andrés Barbero, en Asunción, Paraguay.

Bossert y Villar elaboran su introducción ampliando una noticia autobiográfica escueta que el propio Schmidt escribió poco antes de su muerte. Siguiendo su orden, analizan la formación adquirida en Alemania que, contrariando las teorías evolucionistas en boga, se halla orientada filosóficamente a reconocer en cada grupo humano un todo coherente, fruto de una historia particular que constituye su alma. Esta pugna por alcanzar la unidad de la especie humana a través de su diversidad se percibe en Schmidt en sus enfoques sobre la lengua y la relación con el ambiente. Allí recibe influencias de Karl von den Steinen y se contacta especialmente con Adolf Bastian, decidido impulsor del trabajo de campo como única forma válida de conocimiento que constituía, además, una etnografía de rescate. En este contexto, las evidencias empíricas de las culturas hallarían en las exhibiciones museográficas el espacio y centro de investigación apropiados a su perspectiva disciplinaria. Uno de estos centros, el Museo de Berlín, fue el paso inicial de célebres antropólogos, como Boas, Frobenius, Radin, además de Schmidt, quien en 1919 se hace cargo de la colección sudamericana. Pronto 
realizaría solitarias investigaciones en el Mato Grosso, área preferencial del círculo de Bastian y terra incognita donde ya había realizado sus propias expediciones Karl von den Steinen.

Frente al indudable vínculo del Museo con el Estado y la política colonial, la fuga fuera del Reich en forma de investigaciones americanistas constituyó asimismo un signo distinto del círculo berlinés de Schmidt, próximo al humanismo alemán encarnado por Humboldt. El propio Bastian se mantuvo alejado de conjeturas teóricas propugnadas tanto por el evolucionismo como por el difusionismo - en especial, contrario a la escuela de los Kulturkreise, que llegaría, a la muerte de Bastian, a convertirse en el paradigma de la etnología alemana asentado en la academia. Schmidt continuó, empero, el camino del empirismo inductivo en la investigación americanista que lo condujo a cierta marginalidad compartida con von den Steinen y Koch-Grümberg.

El relato de los autores acerca de los viajes y las investigaciones de Schmidt sigue sus notas de campo y expone al hombre sereno, innovador y humilde en la convivencia con las gentes del Xingu (Bacairi, Nahucua, Aweti, sin llegar a los Kamayura), atravesando experiencias disímiles, gratas, extenuantes, la colección perdida, las fotografías insólitamente rescatadas. En 1901, se lleva a cabo el viaje al Alto Paraguay y los Guató. En 1910, a los ParesiKozarini. De allí su tesis doctoral sobre el problema de la difusión cultural Arawak resultó un pionero aporte integral al estudio comparativo de esta familia lingüística y sus sociedades. Evidencias de la lengua, la arqueología y la historia reunidas en profunda conexión trazaron su concepción de la "colonización Arawak", tratada con una lógica que orientaba su análisis de economía y estratificación social.

En 1918 fue nombrado director de la sección latinoamericana del Museo de Etnología y luego profesor de Etnología en la Universidad de Berlín. En 1927 realiza su último viaje al Mato Grosso (Bacairi, Kaiabi, Paresi, Umotina - tras la inaccesibilidad Iranche). El panorama en el campo se agravaba, fuera por la cercanía de caucheros, las epidemias de gripe y las guerras internas que en no pocas ocasiones fueron motivo de frustración y registro. Recogió entonces grabados rupestres en el Alto Paraguay para retornar a Alemania en 1928, concluyendo su colaboración con el Museo de Berlín y estableciéndose en Brasil en 1929. Se alejaba en el preciso momento en que comenzaba el ascenso del nacional-socialismo y su asfixiante atmósfera de persecución y delación. Muy pronto, sin embargo, se hallaría nuevamente organizando las colecciones del futuro Museo de Historia Natural y Etnografía de Asunción a instancias de su médico, mecenas y amigo Andrés Barbero. Luego de la Guerra del Chaco entre Bolivia y Paraguay por el Chaco Boreal (1932-1935), Schmidt pudo visitar 


\section{MARÍA CRISTINA DASSO. BOSSERT. RESCATE DE UN ENFOQUE ETNOGRÁFICO VELADO EN LA HISTORIA}

campamentos de diversos grupos del Chaco (Wichí, Chanés, Isoseño, Chiriguano, Tapieté, Nivaklé, Chorote, Toba) aún afectados por aquella sangrienta etapa. Accedió entonces a palpar la fluidez lingüística e intercultural chaqueña que ejemplarmente apareció entre los Tapieté mientras pugnaba por colectar objetos para el Museo. Los procesos de aculturación y mestizaje ocuparon buena parte de sus reflexiones.

Su trabajo etnológico se caracteriza por un riguroso empirismo que sólo en ocasiones deja apreciar el empleo de algunos conceptos generalizadores habituales de su tiempo. El modo en que enfocó su propio trabajo de campo deja ver una innovadora actitud de larga estancia, convivencia, notas de campo, registro lingüístico y ergológico de gran detalle. Hasta su muerte en Asunción, acaecida en 1950, prosiguió con la dirección del Museo Etnográfico, las cátedras de Etnología y Etnografía de la Escuela Superior de Filosofía y la escritura de artículos académicos.

La obra que reseñamos reúne, en su virtuosa elaboración, varios motivos de reflexión. En primer lugar, aflora un tema que con frecuencia acecha al quehacer disciplinario de la Etnografía. Nos referimos a las luces y sombras que la historia de la disciplina y los avatares académicos disponen en relación con destacados etnógrafos. No se trata de un tema trivial, pues en ese destino la obra integral, escritos y marcos teóricos creativamente reformulados, son, cuanto menos, negligentemente relegados al olvido en la enseñanza y la investigación de consulta de las jóvenes generaciones. El olvido y el desconocimiento de quienes nos han precedido empobrecen la mirada y definitivamente condenan empresas que merecerían mejores perspectivas. En segundo lugar, hallamos que el trabajo fotográfico de Schmidt deja ver la vida, el alma y la humanidad de un pueblo y un investigador capaz de captar y plasmar esa dignidad peculiarísima en registros destinados a trascenderlos. Cuando se escribe tanto y a veces tan superficialmente sobre la fotografía etnográfica, el quehacer de Schmidt y su foco justo nos coloca frente a la autenticidad vital de la cultura y la sociedad, de manera irreductible. Esa densidad muda en la imagen es elocuente. En tercer lugar, hallamos un valor incontestable de rescate en la doblemente costosa tarea de producir el don de esas imágenes, proporcionándonos generosamente una oportunidad de aprendizaje integral conforme se miran, observan y estudian. El análisis profundo, ameno y reposado sobre Max Schmidt es el complemento necesario y suficiente para ver y comprender su etnografía implícita.

"Ahora sólo entiendo al hombre cuando estoy lejos de él y vivo en soledad" (Prefacio, vi). La cita de Hölderlin que abre la obra permanece con sus ecos en el espíritu del lector, pues queda en él la impresión de que Max Schmidt no logró alejarse de esos grupos 
humanos, misteriosos de costumbre y ambiente, cuya vida fascinó su propia existencia. En efecto, la Etnografía, disciplina de desarraigo que supo cobrarse numerosos y más o menos desconocidos cultores, cuyo rescate debería resultarnos un deber y un derecho, podría hallar en este trabajo un ejemplo capaz de propiciar la renovación de enfoques, el incentivo personal y reforzar la vocación de ver que se requiere para seguir sondeando humanidades. 